\title{
On a collection of Leucosioidea (Crustacea, Decapoda, Brachyura) from Papua New Guinea, with the description of a new species
}

\author{
Bella S. GALIL \\ National Institute of Oceanography, Israel Oceanographic \& Limnological Research, P.O.B. 8030, \\ Haifa 31080, Israel. Email: bella@,ocean.org.il \\ urn:1sid:zoobank.org:author:C2D486BE-E84C-4891-BD57-23C9AF531064
}

\begin{abstract}
The collection of deep-sea pebble crabs (Leucosioidea) during the BIOPAPUA Expedition, comprising 8 species, including a species new to science, is significant because although the previously described species had not been recorded from the Bismarck and western Solomon Seas, they occurred in at least one nearby location (New Caledonia, Vanuatu, Solomon Is). Praebebalia fungifera sp. nov. is described and illustrated. It differs from its closest congener, P. septemspinosa Sakai, 1983, in bearing fungiform granules dorsally on carapace, shorter chelipeds, the relatively stout male first gonopod with a preapical row of setae and the beak-like tip, as compared to the rounded granules dorsally on the carapace, greatly elongate chelipeds and the slim, elongate, distally curved gonopod of P. septemspinosa, preapically set with very long setae and a hook-like tip.
\end{abstract}

Keywords. Decapoda, Leucosiidae, Praebebalia sp. nov., Papua New Guinea, new records.

Galil B.S. 2015. On a collection of Leucosioidea (Crustacea, Decapoda, Brachyura) from Papua New Guinea, with the description of a new species. European Journal of Taxonomy 155: 1-10. http://dx.doi.org/10.5852/ejt.2015.155

\section{Introduction}

Papua New Guinea $(\mathrm{PNG})$ is considered as a region of high marine biodiversity. It is centrally located in the Indo-Pacific gradient of biodiversity and referred to as the coral triangle. However, the biological data of its deep-sea areas are still largely unavailable and these seas are poorly explored by marine biologists. The current body of knowledge on the New Guinean deep sea benthic fauna stems almost exclusively from the study of highly specialized hydrothermal vents. As data on other benthic habitats are missing, patterns of possible faunal connectivity across the deep waters of the western Pacific Ocean remain vague (Pante et al. 2012).

Over the past decade the need for metals has rocketed, making deep-sea deposits increasingly appealing to commercial operators. The most likely targets for deep-sea mining are polymetallic sulphides, manganese nodules and cobalt-rich ferromanganese crusts. Deep seabed mining is emerging as a locally significant anthropogenic stressor through emission of toxic materials and discharge of fine particulate material, though their spatial and temporal scales depend on the particular habitat and the technology utilized. The seabed of the Bismarck and Solomon Seas harbors immense polymetallic sulphide deposits formed around submarine volcanic arcs that precipitate from hydrothermal fluid at the vicinity of 
hydrothermal vent sites (Hoagland et al. 2010). In 2011 the government of PNG licensed deepwater copper and gold mining in the Bismarck Sea. Production at the 'Solwara 1' mine, located at a depth of $1600 \mathrm{~m}$ in the Bismarck Sea, had been scheduled for late 2013. A recently resolved legal dispute with the government of PNG has the license holder targeting production in three years (http://www. businessadvantagepng.com/nautilus-targets-solwara-1-production-three-years). The potential seabed wealth of high-value strategic ores had already drawn intense commercial interest. PNG, Tonga, Fiji, the Solomon Islands, Vanuatu and New Zealand have issued exploration licenses to assess the commercial feasibility of mineral resources development in their EEZs and mining will potentially affect extensive areas of the seabed (http://www.nautilusminerals.com/s/Home.asp).

It is, therefore, with a sense of urgency that the benthic biodiversity of the unique Bismarck Sea and West Solomon Sea, barely explored and due for destructive exploitation, is studied. Many deep-sea habitats extend over large areas, but the extent of individual species and habitat ranges is largely unknown. Greater knowledge is needed on the species diversity and range in order to gauge connectivity, resilience and recovery of deep-sea fauna. The purpose of the BIOPAPUA Expedition, conducted in 2010 by the Muséum National d'Histoire Naturelle, Paris (MNHN), Institut de Recherche pour le Développement (IRD) and the University of PNG, was to explore remote and uncharted territory and to describe the deep benthic fauna in the southwestern Pacific. BIOPAPUA was designed to sample specific habitats and to examine the deep benthic biodiversity in the Bismark Sea and in the western Solomon Sea (in the EEZ of PNG) in order to understand patterns of faunal connectivity across the deep waters of the western Pacific Ocean (Pante et al. 2012). This research is critically relevant as commercial, political and public interest in the exploitation of the deep seabed increases.

The present collection, comprising 8 species, including a species new to science, is significant for although prior to the BIOPAPUA expedition the previously described species have not been recorded from the

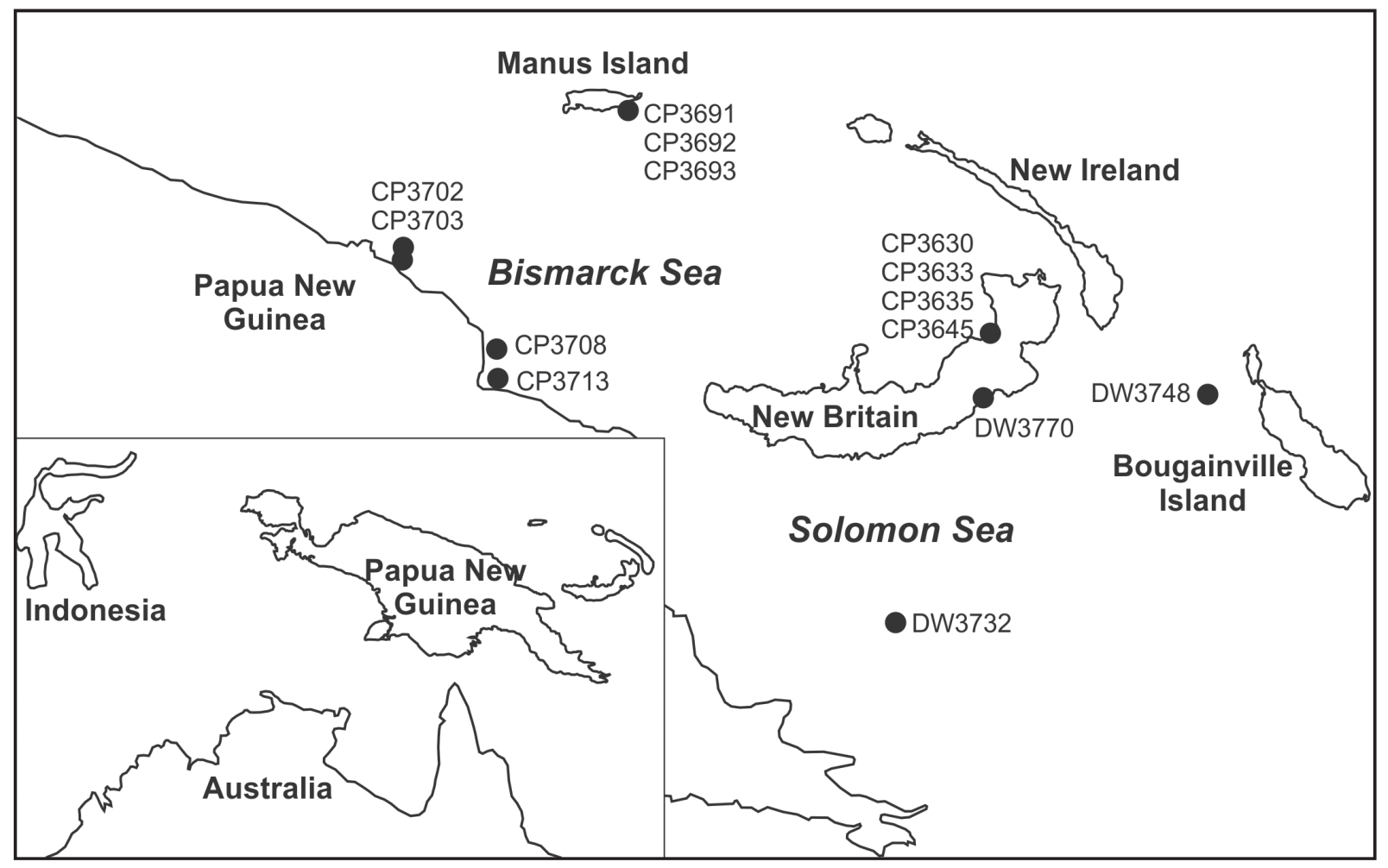

Fig. 1. Map of Papua New Guinea with stations cited in this paper. 
Bismarck and western Solomon seas, they occurred in at least one nearby location (New Caledonia, Vanuatu, Solomon Is), and three species have been recorded in all three. Clearly, this small collection of leucosioids, collected at shelf and mid-slope depths, is insufficient for discerning biogeographic patterns and more extensive studies on the deep slope and bathyal leucosioids are needed. Indeed, a subsequent expedition to Madang Province, in 2012, provided a richer leucosioid collection comprising 25 species, seven of which were new to science and 15 species were new records for Papua New Guinea (Galil \& Ng 2015).

\section{Material and methods}

The BIOPAPUA research cruise aboard R/V 'Alis', took place between 21 Aug. and 19 Oct. 2010. 156 stations were sampled at depths between 100 and $1300 \mathrm{~m}$ in the Bismarck Sea and in the western Solomon Sea. Stations cited in this paper are mapped (Fig. 1). The standard French beam trawl is $4 \mathrm{~m}$ wide, $0.35 \mathrm{~m}$ high, with a conical sac of fine mesh $(15,12 \mathrm{~mm})$ and double-layered cod-end. The trawl is generally deployed at 2.5-4.5 knots and towed at 1.5 knots ground speed. The Warén dredge, with an inner sac of fine mesh (3-5 $\mathrm{mm}$ ) protected by one or two outer layers of coarse mesh $(20-50 \mathrm{~mm})$, was towed at 1-2 knots, or slower, depending on the bottom morphology. The material is deposited in the MNHN, Paris.

Carapace length is measured in $\mathrm{mm}$ along the mid-line from the frontal margin to the posterior margin (not including posterior spine where present).

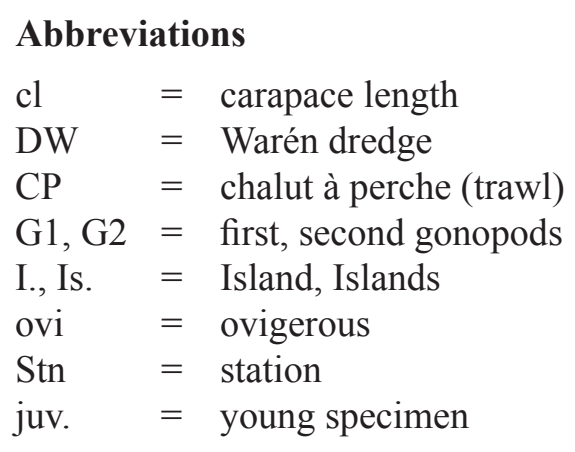

\section{Results}

Infraorder Brachyura Latreille, 1802

Superfamily Leucosioidea Samouelle, 1819

Family Iphiculidae Alcock, 1896

Genus Pariphiculus Alcock, 1896

Pariphiculus agariciferus Ihle, 1918

Pariphiculus agariciferus Ihle, 1918: 250, fig. 136 (type locality: Rote I., Lesser Sunda Is., Indonesia).

Pariphiculus agariciferus - Galil \& Ng 2007: fig. 3b (color photo).

\section{Material examined}

PAPUA NEW GUINEA: Jacquinot Bay, BIOPAPUA Stn DW 3770, 05³4' S, 151³2’ E, 220-294 m, 16 Oct. 2010, 1 q, cl 12.4 mm (MNHN-IU-2011-3871).

\section{Distribution}

Indonesia, South China Sea, Philippines, Japan, Vanuatu (Galil \& Ng 2007, 2010). 
Family Leucosiidae Samouelle, 1819

Subfamily Ebaliinae Stimpson, 1871

Genus Arcania Leach, 1817

Arcania gracilis (Henderson, 1893)

Arcania septemspinosa var. gracilis Henderson, 1893: 403 (type locality: Gulf of Martaban, Myanmar). Arcania gracilis - Galil 2001a: 184, figs 2c, 5d, synonymy. — Galil \& Ng 2007: 82, fig. 1f(color photo).

\section{Material examined}

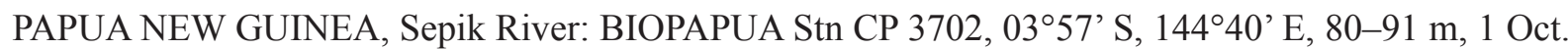
2010, 1 ㅇ, ovi, cl $14.7 \mathrm{~mm} ; 1$, cl $14.1 \mathrm{~mm}$ (MNHN-IU-2013-7013). BIOPAPUA Stn CP 3702, $03^{\circ} 57^{\prime}$

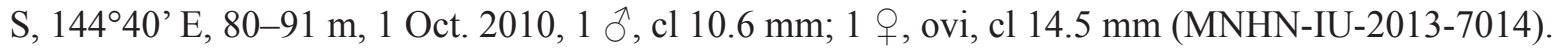

\section{Distribution}

Red Sea to Solomon Is, Vanuatu, New Caledonia; at depths of 21-366 m (Galil 2001, 2007; Galil \& Ng 2007, 2010).

\section{Arcania septemspinosa (Fabricius, 1787)}

Cancer septemspinosus Fabricius, 1787: 325 (type locality: Indian Ocean).

Arcania septemspinosa - Galil 2001a: 193, figs 3b, 7b, synonymy. — Galil \& Ng 2007: 87, fig. 2a (color photo).

\section{Material examined}

PAPUA NEW GUINEA, Sepik River: BIOPAPUA Stn CP 3702, 03ํำ' S, $144^{\circ} 40^{\prime}$ E, 80-91 m, 1 Oct. 2010, 1 \% , cl $16.1 \mathrm{~mm}$; 1 \%, parasitized, cl $16.8 \mathrm{~mm}$; 1 juv. (MNHN-IU-2011-2276). BIOPAPUA Stn CP 3703, 035' 5 ', $144^{\circ} 41^{\prime}$ E, 361-750 m, 1 Oct. 2010, 1 q, cl 16.8 mm (MNHN-IU-2011-1833).

\section{Remarks}

The fauna collected at stations CP3702 and CP3703 comprised seep fauna, i.e., mussels, clams, siboglonid polychaetes. The specimens of $A$. septemspinosa may have been collected in their vicinity.

\section{Distribution}

Red Sea to Australia, Vanuatu, Fiji, at depths of 7-182 m depth (Galil 2001a; Galil \& Ng 2009, 2010).

Genus Parilia Wood-Mason, 1891

\section{Parilia major Sakai, 1961}

Parilia major Sakai, 1961: 137, pl. 3, fig. 5 (type locality: Tosa Bay, Japan).

\section{Material examined}

PAPUA NEW GUINEA, Huon Gulf: BIOPAPUA Stn CP 3630, 06 ${ }^{\circ} 54^{\prime}$ S, $147^{\circ} 03^{\prime}$ E, 305-307 m, 22 Aug. 2010, 1 \% , ovi, cl 45.8 mm (MNHN-IU-2011-1133); 1 ㅇ, ovi, cl 45.0 mm (MNHN-IU-2011-1520). BIOPAPUA Stn CP 3633, 06 54' S, $147^{\circ} 05^{\prime}$ E, 395-406 m, 22 Aug. 2010, 1 ㅇ, cl 47.5 mm (MNHN-

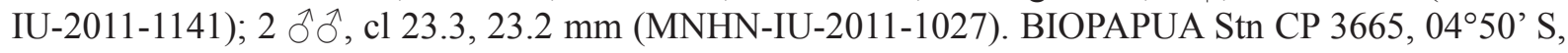
151 $38^{\prime}$ ' E, 225-340 m, 23 Sep. 2010, 1 ô, cl 38.3 mm (MNHN-IU-2011-1368). 
GALIL B.S., Leucosioidea from Papua New Guinea

\section{Distribution}

Indonesia, Philippines, Taiwan, Japan, Solomon Is, 90-425 m (Galil 2007, Galil \& Ng 2007).

Genus Praebebalia Rathbun, 1911

Praebebalia fungifera sp. nov.

urn:1sid:zoobank.org:act:AC7FB29B-FC85-4218-98FA-BAEB3162ECC6

Figs $2-3$

\section{Etymology}

From fungus L., mushroom, for the fungiform granules on the dorsal surface of the carapace.

\section{Material examined}

Holotype

PAPUA NEW GUINEA: ${ }^{\uparrow}$, cl 8.8 mm, SE of Manus I., BIOPAPUA Stn CP 3693, 02¹0’ S, $147^{\circ} 17^{\prime} \mathrm{E}$, 300 m, 29 Sep. 2010 (MNHN-IU-2013-5996).

\section{Paratypes}

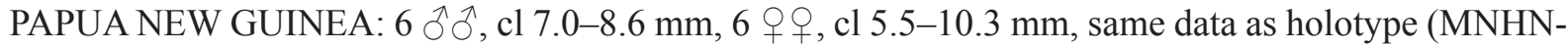

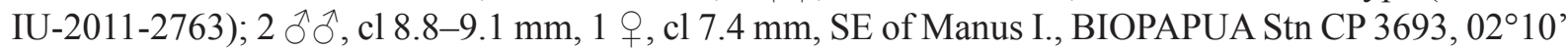
S, $147^{\circ} 17^{\prime}$ E, 300 m, 29 Sep. 2010 (MNHN-IU-2011-2209); 1 ô, cl 8.5 mm, E of Manus I., BIOPAPUA

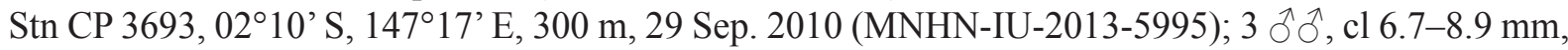

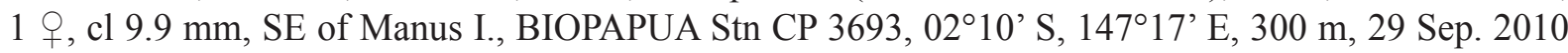
(MNHN-IU-2011-2107).

\section{Description}

Carapace globose, pyriform, regions ill-defined. Dorsal surface of carapace set with flat-topped, fungiform granules, five granulate tubercles medially, intestinal tubercle largest, conical (Fig. 2). Postorbital region

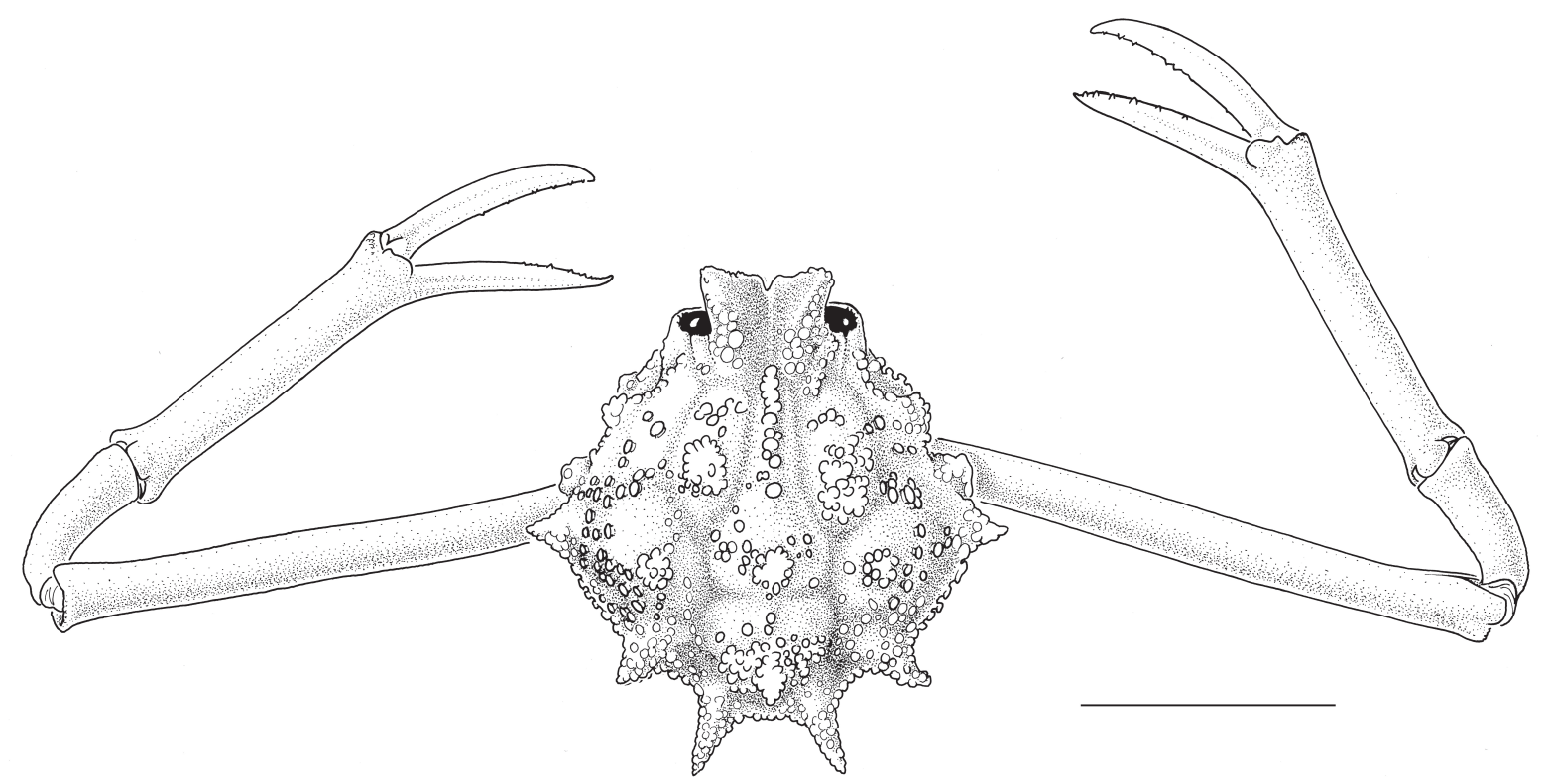

Fig. 2. Praebebalia fungifera sp. nov., holotype, §ิ ( $8.8 \mathrm{~mm}$ ) (MNHN-IU-2013-5996). Carapace and chelipeds, dorsal view. Papua New Guinea. 

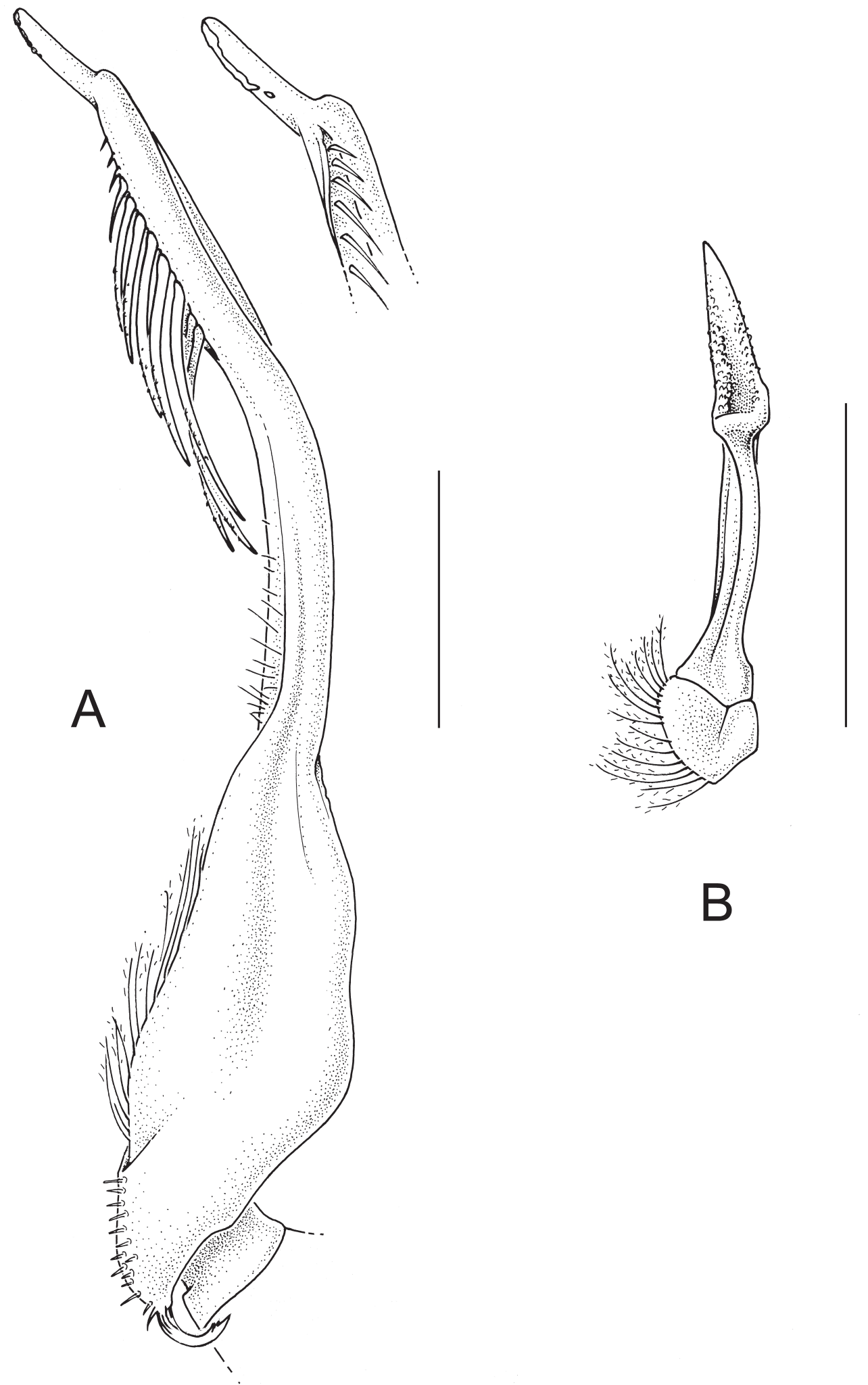

B

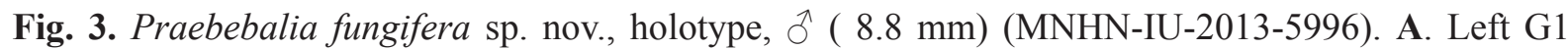
(ventral view), distal part of left G1 (dorsal view). B. Left G2. Scales: A-B =1.0 mm. 
concave. Row of nearly contiguous agariciform granules medially to cardiac region. Intestinal region tumescent, faintly demarcated by shallow grooves. Front prominent, bilobed, frontal lobes tumid, widened anteriorly, minutely granular, setose. Eyes small. Orbital margin bifissured dorsally, V-shaped fossa laterally; infraorbital lobe spiniform, prominent. Antennules obliquely folded, basal antennular segment sealing lower antennular aperture. Antennae small, slender, basal antennal segment inserted in inner orbital hiatus. Buccal frame trapezoid, narrowing antedorly. Third maxilliped bearing prominent agariciform granules; exognath slightly shorter, more slender than endognath, merus more than half as long as ischium. Anterior margin of efferent branchial channel unifissured, apparent in dorsal view, curved distad. Anterolateral margins of carapace with two subequal fungiferous tubercles; subhepatic margin visible in dorsal view, closely set anteriorly with agariciform granules, subhepatic tubercle fungiferous. Midlateral and posterolateral tubercles conical, set with fungiform granules, smaller, closer-set distally. Posterior margin of carapace bituberculate, tubercles conical, slender, proximally bearing fungiferous granules, distally upcurved. Chelipeds slender, subcylindrical, minutely granular, very long; merus in adult male $1.3 \times$ as long as carapace; propodus somewhat thicker distally, fingers two-thirds as long as propodus, tips crossing when closed. Ambulatory legs slender, short, dactyls long, setose. Thoracic sternites granular. Sternoabdominal cavity deep, elongate, nearly reaching buccal cavity, margins lamellate in female. Male abdomen with somites 3-5 fused, narrowing distally, basiolateral regions of fused somites inflated. Lateral margin of somite 6 ridged medially, fitting into groove at seam between plastron and sternite 5 . Telson longer than sixth abdominal somite, bearing conical tooth basally. Adult female abdomen with somites 3-6 fused, greatly swollen, telson laciniate. G1 with stout basal stalk, flanged on interior margin, tapering, distally curved distad, preapically set with long, microscopically serrate setae, tip beak-like; G2 short, distally scoop-like (Fig. 3). Vulvae submedially on sternite 5 , near suture 4/5; gonopore round, small, directed anteriorly, slightly raised rim posteriorly.

\section{Remarks}

Of the 12 species assigned to the genus Praebebalia Rathbun, 1911, only two (P. extensiva Rathbun, 1911 and P. septemspinosa Sakai, 1983) were retained in the genus following revision and two were newly described (P. madagascariensis Galil, 2001 and P. magna Galil, 2001) (Galil 2001b). The genus is characterized by its subcircular, globose carapace, with tubercle medially on lateral margin; bilobed front; conical intestinal region; lateral angles of posterior margin of carapace prominently spinose; male abdomen with somites 3-5 fused; G1 elongate, preapically set with long setae; and very long chelipeds. Praebebalia fungifera $\mathrm{sp}$. nov. differs from the western Indian Ocean species, $P$. madagascariensis (Madagascar), P. magna (Madagascar, Mozambique) and P. extensiva (Seychelles, Saya de Malha Bank), in its flat-topped, fungiform granules on the dorsal surface of the carapace and a spine on the posterolateral margin; it differs from P. septemspinosa (Philippines), with which it shares the latter character, in its shorter chelipeds (1.3 as compared to twice as long as carapace), and G1 relatively stout, slightly bent distad, preapically set with setae, tip beak-like (Fig. 3), as compared to the elongate, distally curved G1 of P. septemspinosa, preapically set with very long setae, tip hook-like (Galil 2001b: fig $4 \mathrm{~b}-\mathrm{c})$.

\section{Distribution}

Known only from the type location, Manus I., Papua New Guinea; $300 \mathrm{~m}$.

Genus Tanaoa Galil, 2003

Tanaoa nanus Galil, 2003

Tanaoa nanus Galil, 2003: 403, figs lc, 3e-f (type locality: Vanuatu, 16²9.23’ S, 16758.70’ E). 


\section{Material examined}

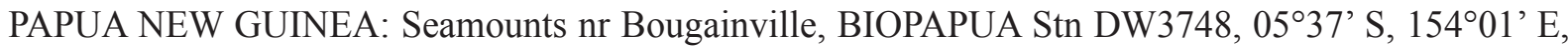
398-399 m, 12 Oct. 2010, 1 ð , cl 15.5 mm (MNHN-IU-2011-5254). Madang, BIOPAPUA Stn CP 3708,

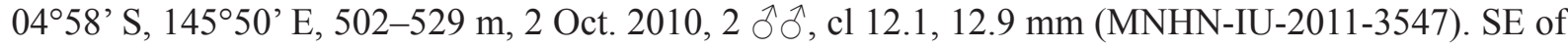

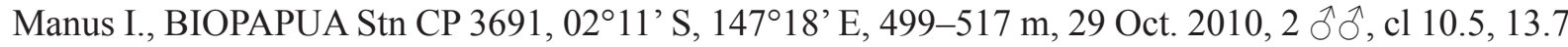
mm (MNHN-IU-2011-2694). Astrolabe Bay, BIOPAPUA Stn CP 3713, 05²2' S, 14550' E, 608-610

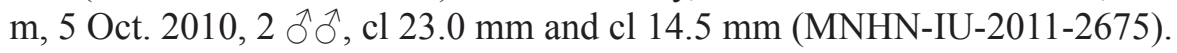

\section{Distribution}

Indonesia, Solomon Is, Vanuatu, New Caledonia, Wallis I.; 281-1250 m (Galil 2007).

Genus Toru Galil, 2003

Toru pilus (Tan, 1996)

Randallia pila Tan, 1996: 1051, fig. 4g-h, 71-n, 8a-f(type locality: Philippines, $13^{\circ} 12^{\prime}$ N $123^{\circ} 50.30^{\prime}$ E).

Toru pilus - Galil 2003: 412, figs 28, 5a-b.

\section{Material examined}

PAPUA NEW GUINEA: SE of Manus I., BIOPAPUA Stn CP 3692, 02 $10^{\prime}$ S, $147^{\circ} 19^{\prime}$ E, 408-448 m, 29 Sep. 2010, 5 ふैं, cl 11.4-12.1 mm (MNHN-IU-2011-3439). SE of Manus I., BIOPAPUA Stn CP

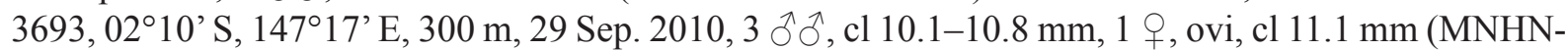
IU-2011-2745); $2 \hat{\jmath} \widehat{\jmath}$, cl 11.2-11.4 mm, 1 क, ovi, cl 11.9 mm (MNHN-IU-2011-2282). Lancasay Is., BIOPAPUA Stn DW 3732, $08^{\circ} 16^{\prime}$ S, 150²9’ E, 340-358 m, 9 Oct. 2010, 1 ô, cl 9.2 mm (MNHNIU-2011-1174).

\section{Distribution}

Philippines, Solomon Is, Vanuatu, New Caledonia, Fiji; 234-620 m (Galil 2007).

Genus Urashima Galil, 2003

Urashima pustuloides (Sakai, 1961)

Randallia pustuloides Sakai, 1961: 135, pl. 3, fig. 4 (type locality: Tosa Bay, Shikoku I., Japan).

Urashima pustuloides - Galil 2003: 417, figs 2h, 5g-h.

\section{Material examined}

PAPUA NEW GUINEA: Huon Gulf, BIOPAPUA Stn CP 3633, 0654’ S, 14705’ E, 395-406 m, 22 Aug. 2010, 1 ㅇ, cl 28.0 mm (MNHN-IU-2011-3314). Huon Gulf, BIOPAPUA Stn CP 3635, 07²9’ S,

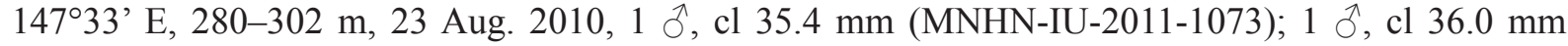
(MNHN-IU-2011-1525). Huon Gulf, BIOPAPUA Stn CP 3645, 06²44' S, 14750' E, 403-418 m, 24 Aug. 2010, 1 ô, cl 41.0 mm, photo (MNHN-IU-2011-3864). SE of Manus I., BIOPAPUA Stn CP 3692,

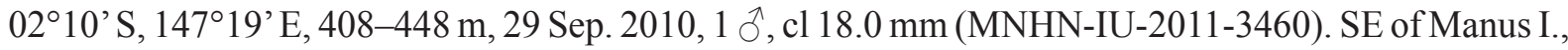
BIOPAPUA Stn CP 3693, 02 $10^{\prime}$ S, 147¹7’ E, 300 m, 29 Sep. 2010, 1 juv. (MNHN-IU-2011-2751).

\section{Distribution}

Indonesia, Philippines, Taiwan, Japan, Solomon Is, Australia; 50-839 m (Galil 2007; Galil \& Ng 2007). 
GALIL B.S., Leucosioidea from Papua New Guinea

\section{Acknowledgements}

The specimens from deep water off Papua New-Guinea were collected by R.V. Alis during the BIOPAPUA cruise in September 2010, under the leadership of PIs Dr Sarah Samadi and Laure Corbari. The cruise was operated by the Muséum National d'Histoire Naturelle (MNHN) and the Institut de Recherche pour le Développement (IRD) as part of the research program "Tropical Deep Sea Benthos", PIs Sarah Samadi and Philippe Bouchet. The expedition operated under a permit granted by the Department of Environment and Conservation (DEC) of Papua New-Guinea.

Sincere thanks are extended to Laure Corbari, Anouchka Sato and Paula Martin-Lefevre for the loan of the specimens, and to Jean-François Dejouannet (IRD; MNHN), for the accompanying illustrations. I thank H. Komatsu and P.K.L. Ng for their comments.

\section{References}

Fabricus J.C. 1787. Mantissa Insectorum sistens eorum Species nuper detectas adiectis Characteribus genericis, Differentiis specificis, Emendationibus, Observationibus. I: i-xx, 1-348. C.G. Proft, Copenhagen. http://www.biodiversitylibrary.org/bibliography/36471\#/summary

Galil B.S. 2001a. A revision of the genus Arcania Leach, 1817 (Crustacea: Decapoda: Leucosioidea). Zoologische Mededelingen 75 (11): 169-206. Available from http://www.repository.naturalis.nl/ document/45064 [accessed on 5 Sep. 2015]

Galil B.S. 2001b. A revision of the genus Praebebalia Rathbun, 1911 (Brachyura, Leucosioidea). Journal of Crustacean Biology 21 (1): 266-274. http://dx.doi.org/10.1651/0278-0372(2001)021[0266:AROTG P]2.0.CO;2

Galil B.S. 2003. Four new genera of leucosiid crabs (Crustacea: Brachyura: Leucosiidae) for three new species and nine species previously in the genus Randallia Stimpson, 1857, with a redescription of the type species, $R$. ornata (Randall, 1939). Proceedings of the Biological Society of Washington 116 (2): 395-422. http://www.biodiversitylibrary.org/part/44479

Galil B.S. 2007. The deep-water Calappidae, Matutidae and Leucosiidae of the Solomon Islands, with a description of a new species of Euclosia Galil, 2003 (Crustacea, Decapoda, Brachyura). Zoosystema 29: $555-563$.

Galil B.S. \& Ng P.K.L. 2007. Leucosiid crabs from Panglao, Philippines, with descriptions of three new species (Crustacea: Decapoda: Brachyura). Raffles Bulletin of Zoology Supplement 16: 79-94.

Galil B.S. \& Ng P.K.L. 2009. Calappoidea and Leucosioidea (Crustacea; Decapoda; Brachyura) from Luzon, Philippines, with descriptions of two new species of Mursia. Zootaxa 2085: 45-60.

Galil B.S. \& Ng P.K.L. 2010. On a collection of calappoid and leucosioid crabs (Crustacea; Decapoda;Brachyura) from Vanuatu, with description of a new species. In: Castro P., Davie P.J.F., Ng P.K.L. \& Richer de Forges B. (eds) Studies on Brachyura: a Homage to Danièle Guinot. Crustaceana Monographs. 11: 139-152. Brill, Leiden.

Galil B.S. \& Ng P.K.L 2015. Leucosiid crabs from Papua New Guinea, with descriptions of eight new species (Crustacea: Decapoda: Brachyura). Zootaxa 4027 (4): 451-486. http://dx.doi.org/10.11646/ zootaxa.4027.4.1

Henderson J.R. 1893. A contribution to Indian carcinology. Transactions of the Linnean Society 5 (2): 325-548. http://dx.doi.org/10.1111/j.1096-3642.1893.tb00653.x

Hoagland P., Beaulieu S., Tivey M.A., Eggert R.G., German C., Glowka L. \& Lin J. 2010. Deepsea mining of seafloor massive sulfides. Marine Policy 34: 728-732. http://dx.doi.org/10.1016/j. $\underline{\text { marpol.2009.12.001 }}$ 
Ihle J.E.W. 1918. Die Decapoda Brachyura der Siboga-Expedition. III. Oxystomata: Calappidae, Leucosiidae, Raninidae. Siboga Expeditie 39b2: 1-322.

Pante E., Corbari L., Thubaut J., Chan T.-Y., Mana R., Boisselier M.-C., Bouchet P. \& Samadi S. 2012. Exploration of the deep-sea fauna of Papua New Guinea. Oceanography 25 (3): 214-225. http://dx.doi. org/10.5670/oceanog.2012.65

Sakai T. 1961. New species of Japanese crabs from the collection of His Majesty the Emperor of Japan. Crustaceana 3 (2): 131-150. http://dx.doi.org/10.1163/156854061X00635

Tan C.G.S. 1996. Leucosiidae of the Albatross expedition to the Philippines, 1907-1910 (Crustacea: Brachyura: Decapoda). Journal of Natural History 30: 1021-1058. http://dx.doi. org/10.1080/00222939600770551

Manuscript received: 6 September 2015

Manuscript accepted: 8 October 2015

Published on: 23 November 2015

Topic editor: Rudy Jocqué

Desk editor: Kristiaan Hoedemakers

Printed versions of all papers are also deposited in the libraries of the institutes that are members of the EJT consortium: Muséum National d'Histoire Naturelle, Paris, France; Botanic Garden Meise, Belgium; Royal Museum for Central Africa, Tervuren, Belgium; Natural History Museum, London, United Kingdom; Royal Belgian Institute of Natural Sciences, Brussels, Belgium; Natural History Museum of Denmark, Copenhagen, Denmark. 